\title{
Significance of advection for the carrying capacities of fjord populations
}

\author{
D. L. Aksnes ${ }^{1}$, J. Aure ${ }^{2}$, S. Kaartvedt ${ }^{1}$, T. Magnesen ${ }^{1}$, J. Richard ${ }^{1, *}$ \\ ${ }^{1}$ Department of Marine Biology, University of Bergen, N-5065 Blomsterdalen, Norway \\ ${ }^{2}$ Institute of Marine Research, Directorate of Fisheries, PO Box 1870, N-5024 Bergen, Norway
}

\begin{abstract}
Advective rates of nutrients, phytoplankton and zooplankton were estimated for the Masfjord, western Norway, in June and October 1985. The advective contribution to the phytoplankton biomass formation was clearly less than the local growth. Advection of nutrients, even below the photic zone, may have large implications for the new production of the fjord. The highest renewal rate $\left(13.6 \% \mathrm{~d}^{-1}\right)$ due to advection was obtained for the mesozooplankton in June. While $20 \%$ of this renewal was due to water advection alone, $80 \%$ was due to the combined effect of the current profile and the vertical distribution of the mesozooplankton. Thus transport of mesozooplankton may exceed local growth significantly. The deep basin $(494 \mathrm{~m})$ of the fjord serves as a refuge for resident macrozooplankton and micronekton populations predating on mesozooplankton. Analysis suggests that such predators may be more sensitive to a change in the advective rate than to a similar change in the prey growth rate. Advection may be an important factor underlying the carrying capacity of mesozooplankton predators in fjords.
\end{abstract}

\section{INTRODUCTION}

Norwegian fjords are presently being considered as a biotope for sea-ranching of different organisms. The carrying capacities of a fjord, with respect to such organisms, have therefore become parameters of considerable interest. Carrying capacity depends on the productivity and structure of the system, and a crucial question is therefore: To what extent are these factors influenced by boundary conditions rather than by local processes within the system? Platt \& Conover (1971) made an intensive $25 \mathrm{~h}$ study to estimate the terms (production, transport and grazing) of the continuity equation of phytoplankton formulated for the Bedford basin. They found that $58 \%$ of daily phytoplankton production was lost through exchange (mainly tidal) across the sill. Lindahl \& Perissinotto (1987) and Lindahl \& Hernroth (1988) concluded that non-tidal advection was of major importance in the regulation of the mesozooplankton biomass of the Gullmar fjord in Sweden.

As the physical scale of fjords varies, the balance between internal and external forcing is also likely to

- Present address: Dunstaffnage Marine Research Laboratory, PO Box 3, Oban, Argyll PA34 4AD, Scotland vary. The cross-sectional area above the sill is therefore an important boundary property, and the ratio between the cross-sectional area and the total fjord volume may indicate the impact of the sill boundary conditions on the fjord. This ratio varies considerably from one fjord to another. In the fjord system Lindåspollene, western Norway, this ratio is of order $10^{-7}\left(\mathrm{~m}^{-1}\right)$, while the corresponding ratio of Korsfjorden, western Norway, is of order $10^{-4}$. Extensive investigations on the pelagic communities in these fjords have revealed marked differences in biological structure (Matthews \& Heimdal 1980). For example, it has been concluded that Calanus finmarchicus in Korsfjorden is heavily influenced by 'advective production' (Matthews \& Heimdal 1980), while in Lindåspollene the population development within a year is more influenced by internal processes (Aksnes \& Magnesen 1983). Extensive winter/spring renewal of the deep water, however, may seriously affect the 'initial' conditions and give rise to yearly variations in species composition and biomass (Lie et al. 1983). This was also pointed out by Lindahl \& Hernroth (1988) in their study of the Gullmar fjord.

Masfjorden has been selected as a site for mass release of codlings. As recommended by Ulltang (1984) the ecological and economical consequences of such release should be evaluated within a restricted area 
before large-scale enhancement of natural populations is initiated. The study of the factors underlying the carrying capacity for cod is one of the main ecological topics within this project.

In the present study the potential significance of advection in Masfjorden (Fig. 1) is investigated. Masfjorden has a cross-sectional sill area to volume ratio of $8 \times 10^{-6}$ which is intermediate between Lindåspollene and Korsfjorden. Results on the amounts and exchange rates (obtained during 2 short time periods) of nutrients, chl $a$, phaeopigments, and zooplankton are presented, and possible implications of advection are discussed.

\section{STUDY AREA AND METHODS}

Masfjorden (Fig. 1) is separated from the larger fjord, Fensfjorden, by a $75 \mathrm{~m}$ deep sill. Length of the fjord is about $20 \mathrm{~km}$ and width averages $1 \mathrm{~km}$. Other important topographic characteristics are given in Fig. 1 and
Table 1. Tidal amplitude is 0.5 to $1 \mathrm{~m}$, and daily exchange due to tide is about $0.5 \%$. This exchange is not included in the rates presented in our study. These are calculated on the basis of residual currents, which were calculated by a graphic averaging of the current component during the observed tidal cycles. The tidal influence is also left out in the calculation of renewal rates for the biological compartments of the fjord.

The total freshwater supply varies between 30 and $60 \mathrm{~m}^{3} \mathrm{~s}^{-1}$, and amounts to about $0.1 \%$ of total fjord volume per day. Most of the freshwater enters at the head of the fjord, where the outlet from a hydroelectric power plant is located.

Sampling was undertaken during 2 periods: 24 to 28 June and 28 October to 1 November 1985. (The latter period will be referred to as the 'October' sampling.) In these periods, continuous current measurements were made at different depths above the sill, while discrete measurements of nutrients, chla, phaeopigments, mesozooplankton and macrozooplankton content were made above the sill and within

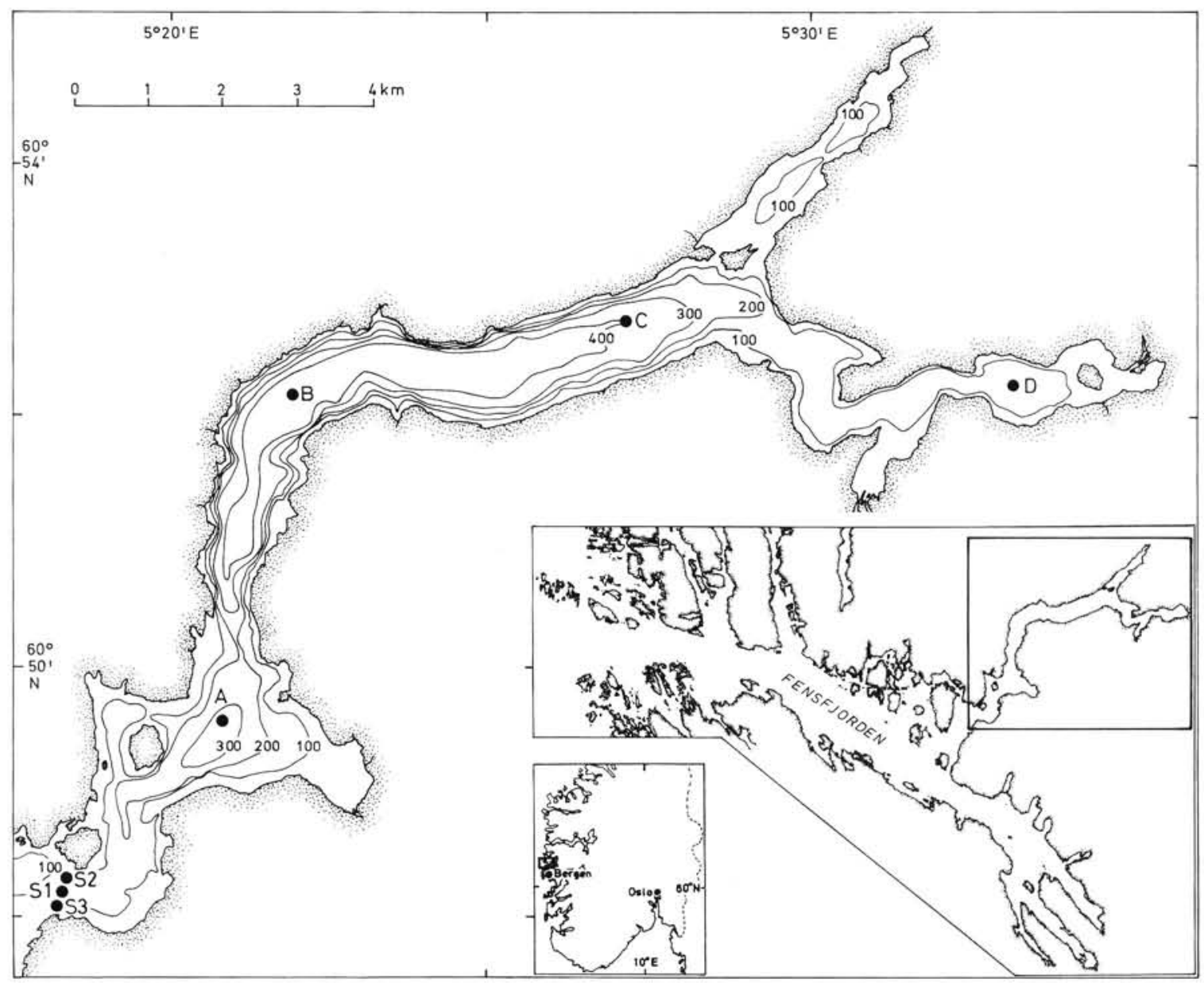

Fig. 1. Masfjorden with sampling stations. S1 to S3 are located at the fjord sill 
Table 1. Topographic characteristics of the fjord

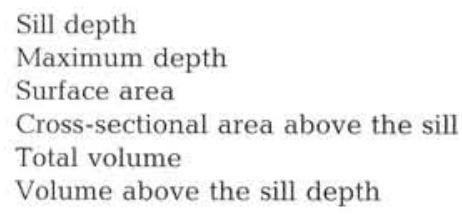

the fjord. Three sampling stations (S1, S2, S3) were located at the sill, and 4 (A, B, C, D) within the fjord (Fig. 1).

Sampling was carried out from RV 'Håkon Mosby' and RV 'Fridtjof Nansen'.

Hydrography and current measurements. During 24 to 28 June automatic current measurements (Sensordata, SD-1000) were conducted at Stns S1, S2 and S3 (Fig. 1). At Stn S1 readings were obtained at 2, 7, 15, 35, 43, 60 and $80 \mathrm{~m}$ depth, and at Stns S2 and S3 at 2 and $35 \mathrm{~m}$. During 28 October to 1 November measurements were carried out at the same depths as above at Stn 1 , but no current measurements were undertaken at Stns S2 and S3. Supplementary measurements in the surface layer $(0$ to $2 \mathrm{~m})$ and at intermediate depths were conducted with a Gytre 16 point current meter (Sensordata) operated from an anchored boat. Estimates of net water transport above the sill during the 2 periods were calculated from residual currents and the cross-sectional area above the sill.

In June, temperature, salinity and oxygen were measured by a Martek-CTDO supplied with $100 \mathrm{~m}$ cable. In October, temperature and salinity were measured using a Neil-Brown CTD, while oxygen content was determined in water samples (Niskin samplers) using the standard Winkler technique.

Nutrients and chlorophyll samples were obtained by Niskin water samplers and with a plankton pump (see below). Subsamples $(30 \mathrm{ml})$ for nutrient analyses were given additions of chloroform, and refrigerated until later analysis. Concentrations of nitrate, phosphate and silicate were measured using a Chemlab Autoanalyser. Subsamples $(100 \mathrm{ml})$ for $\mathrm{chl} a$ and phaeopigment analysis were filtered through $0.45 \mu \mathrm{m}$ Sartorius membrane filters. The filters were frozen, and later analysed by acetone extraction in accordance with Holm-Hansen et al. (1965).

Mesozooplankton sampling was performed in 2 strata, 0 to $50 \mathrm{~m}$ and 50 to $494 \mathrm{~m}$. The upper stratum was defined in accordance with the operational range of a plankton pump, used to get high vertical resolution in the 0 to $50 \mathrm{~m}$. The samples were filtered through a $180 \mu \mathrm{m}$ plankton gauze and each sample represented a volume of about $9 \mathrm{~m}^{3}$. A double Juday-net (aperture $0.125 \mathrm{~m}^{2}$, mesh size $180 \mu \mathrm{m}$ ) equipped with a closing mechanism was used in both strata. One sample was frozen for biomass analysis and another preserved in $4 \%$ formalin for species analysis. Dry weight was determined by drying in a oven at $60^{\circ} \mathrm{C}$ to constant weight, and ash content by burning for $2 \mathrm{~h}$ at $480^{\circ} \mathrm{C}$.

The coefficient of variation $(\mathrm{CV})$ between the plankton pump and the Juday-net biomass samples obtained from the same depth layer (but some hours apart) was on average $22 \%$ (based on 7 comparisons). This CV is comparable to the CV calculated from replicate daytime sampling with a Juday-net (Aksnes 1986), and present biomass estimates (Table 3) are based on combined data for the 2 gears.

Macrozooplankton and mesopelagic fishes were sampled day and night in the deep basin (Stns B and C) and at the sill (S1) in October. An Isaacs-Kidd Midwater Trawl (IKMT) of $10 \mathrm{~m}^{2}$ aperture (Anon. 1981) was fished open at a towing speed of ca 3 knots. The mesh size of the trawl decreased from $25 \mathrm{~mm}$ at the front to $1.15 \mathrm{~mm}$ at the cod-end. Depth was recorded using a Benthos time-depth recorder (model 1170-1000). The volume of water filtered was estimated by multiplying the trawled distance by the net aperture. Displacement volumes of the fishes and macrozooplankton were measured separately for each sample. Subsamples of the macrozooplankton $(1 / 2$ to $1 / 8)$ were frozen for biomass determination. Samples were dried to a constant weight in an oven at $60^{\circ} \mathrm{C}$ and then burned for 6 to $8 \mathrm{~h}$ at $480^{\circ} \mathrm{C}$ to obtain ash weights. A biomass estimate for each sample was obtained by multiplying the subsample AFDW by the displacement volume ratio between the total sample and the subsample, and taking the mean value. The biomass estimates presented for the macrozooplankton (Table 3) were calculated assuming a net aperture of $10 \mathrm{~m}^{2}$, but the effective aperture during sampling is certainly less. These estimates must therefore be regarded as minimum values.

Estimates of total nutrients and mesozooplankton biomass (Table 2) are based on sampling in 2 strata. For nutrients the approximate position of the nutricline ( $20 \mathrm{~m}$ in June and $100 \mathrm{~m}$ in October) was used to divide the fjord into the 2 strata. Estimates of the mesozooplankton are based on the strata 0 to $50 \mathrm{~m}$ and $50 \mathrm{~m}$ to bottom. Confidence limits were obtained according to Cochran (1977, p. 95-96) with the use of Satterthwaites' approximation formula for calculating the effective number of degrees of freedom.

\section{RESULTS}

\section{Hydrography and residual water transport}

The water masses of Masfjorden may be classified as: brackish water ( 0 to $3 \mathrm{~m}$ ); intermediate water, found between the brackish water and the sill depth $(75 \mathrm{~m})$; 
and deep water, found below the sill depth. The intermediate water may be divided into coastal water with salinity below $34.5 \%$ and Norwegian Trench water with salinity above $34.5 \%$.

In June a persistent inflowing residual current was observed between 2 and 25 to $30 \mathrm{~m}$ depth, while an outflowing current was observed below this depth (Fig. 2). Current measurements conducted at $1.5 \mathrm{~m}$ depth (not plotted) also indicated an outflowing current, with a mean velocity of about $10 \mathrm{~cm} \mathrm{~s}^{-1}$ over a tidal cycle. Typical residual current velocites between 2 and $25 \mathrm{~m}$ depth were 8 to $10 \mathrm{~cm} \mathrm{~s}^{-1}$ and 6 to $8 \mathrm{~cm} \mathrm{~s}^{-1}$ below $30 \mathrm{~m}$. Mean out- and in-transport above the sill was about $1600 \pm 100 \mathrm{~m}^{3} \mathrm{~s}^{-1}$ in June. The inflowing water was Norwegian coastal water with salinity below $34.3 \%$ and temperature 8 to $15^{\circ} \mathrm{C}$. The salinity of the outflowing water was close to $34.6 \%$ and the temperature was 7.5 to $8^{\circ} \mathrm{C}$.

The currents observed in October were relatively more influenced by the tidal cycle than in June. The residual currents were about $4 \mathrm{~cm} \mathrm{~s}^{-1}$ (Fig. 2). Maximum observed velocities at inflowing and outflowing tide were 15 to $20 \mathrm{~cm} \mathrm{~s}^{-1}$. The residual current was 3layered with outflow in 0 to $10 \mathrm{~m}$, inflow between 10 to $35 \mathrm{~m}$, and outflow between $35 \mathrm{~m}$ and the sill depth (Fig. 2). Mean net out- and in-transport above the sill was about $500 \pm 100 \mathrm{~cm} \mathrm{~s}^{-1}$, a third of the transport observed in June. Both outflowing and inflowing water above 50 to $60 \mathrm{~m}$ depth were classified as coastal water with temperature 10 to $12{ }^{\circ} \mathrm{C}$ (Fig. 3).

The salinity and temperature of the basin water was $34.99 \%$ and $7.4^{\circ} \mathrm{C}$, and the oxygen content of the deep water was also fairly constant, ranging from 4.7 to $4.9 \mathrm{mll}^{-1}$ (Fig. 3).

\section{Nutrients and biological parameters}

Average concentrations of nitrate, phosphate and silicate below $20 \mathrm{~m}$ depth were estimated as $12.1,1.5$, and $9.1 \mu M$ respectively, which give rise to a large nutrient reservoir in the fjord (Table 2). The low nitrate concentrations above $20 \mathrm{~m}$ (average $0.4 \mu \mathrm{M}$ ) indicate nitrogen-limited growth of phytoplankton in June.

Average concentrations of chl $a$ and phaeopigments in the upper $50 \mathrm{~m}$ were estimated as 0.4 and $0.2 \mathrm{mg} \mathrm{m}^{-3}$ respectively. Average mesozooplankton biomass of the entire fjord volume was estimated as $6.1 \mathrm{mg}$ AFDW $\mathrm{m}^{-3}$. The phytoplankton and mesozooplankton biomasses may be compared by converting the estimates of phytoplankton (0.497 tonne chla) and mesozooplankton (32.8 tonne AFDW) to carbon. Assuming a carbon to chl a ratio of 50 and a carbon to AFDW ratio of 0.5 , it is indicated that the phytoplankton biomass (25 tonne C) and mesozooplankton biomass (16 tonne C) are of the same order of magnitude.

About $50 \%$ of the total mesozooplankton biomass was found in the upper $50 \mathrm{~m}$ (Table 3 ). The day and night vertical distributions were similar, apart from the 0 to $2 \mathrm{~m}$ layer which had a 4 -fold increase at night (Fig. 2). The numerically dominant mesozooplankton in the integrated 0 to $50 \mathrm{~m}$ depth layer were Oithona spp., Temora longicornis, Evadne nordmanni, Calanus finmarchicus and Podon spp.
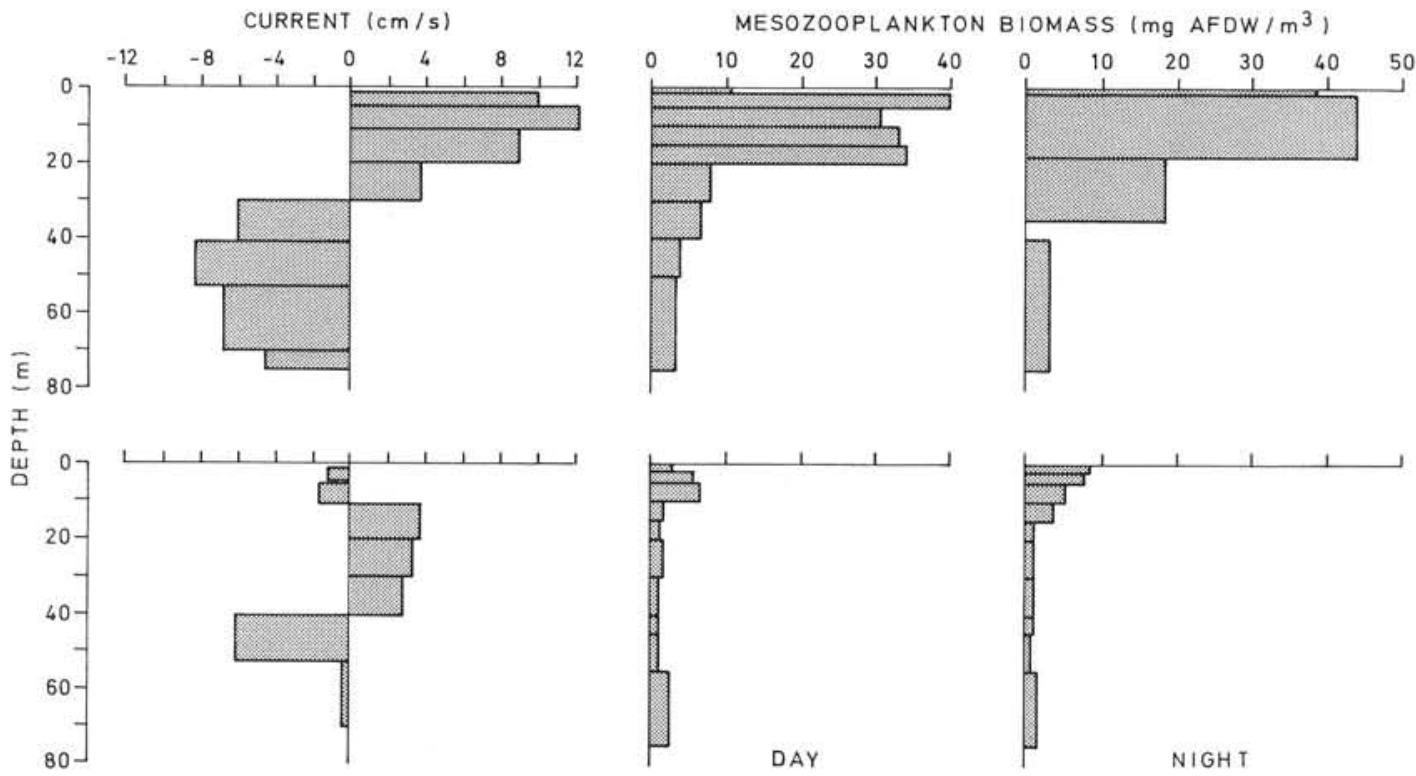

Fig. 2. Vertical distribution of residual currents (averaged for the periods 24 to 28 Jun and 28 Oct to 1 Nov), and mesozooplankton biomass (during day and night) as measured above the sill. Upper profiles: June cruise; lower profiles: October cruise. Positive current values indicate transport into the fjord 


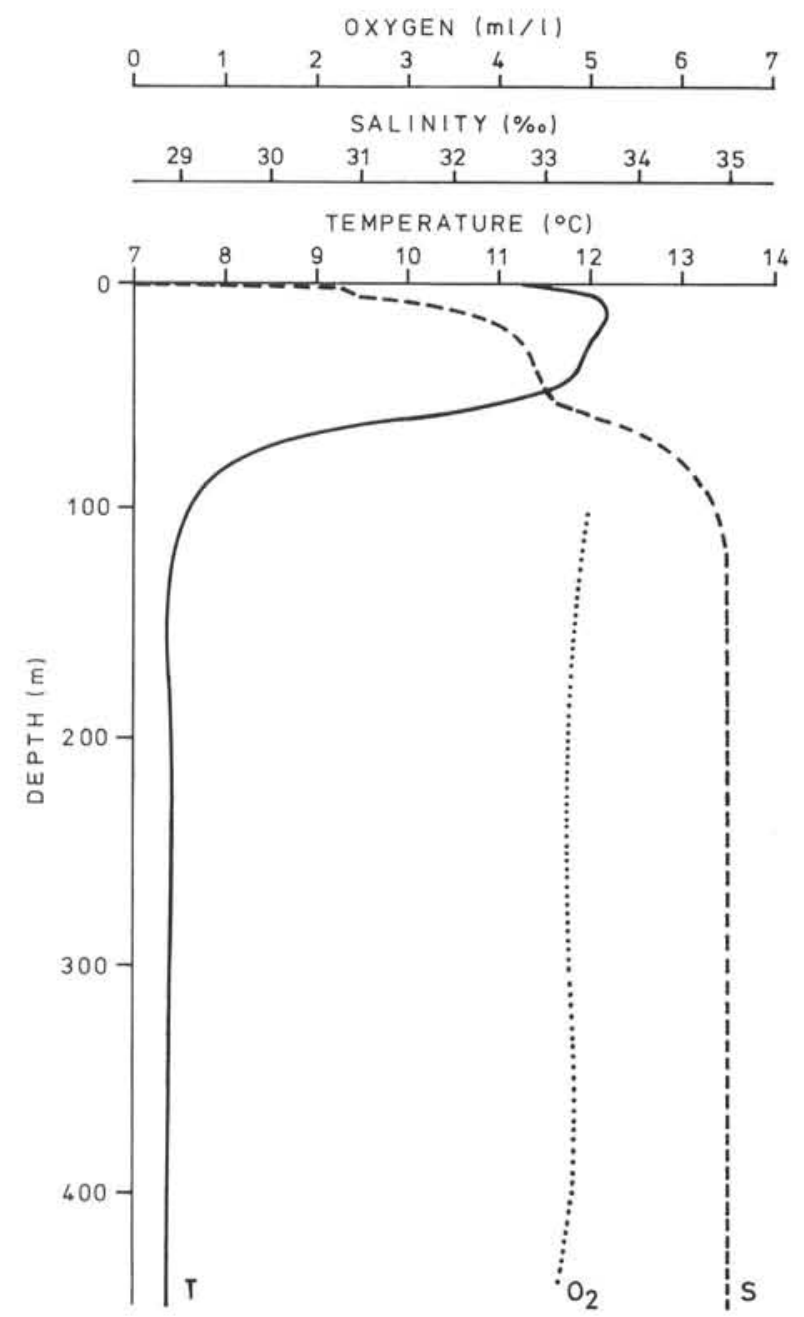

Fig. 3, Vertical distribution of temperature, salinity and oxygen at the deepest station (Stn B) in October 1985

In October the total amount of nitrate in the uppermost $20 \mathrm{~m}$ of the fjord was about 10 times higher ( 31.5 tonne $\mathrm{N}$ ) than in June ( 3.3 tonne N). On the other hand, the amount of phosphate in this layer was highest in June (Table 2). This supports the above suggestion that the phytoplankton production was nitrogen-limited in June.

The total amount of $\mathrm{chl} \mathrm{a}$ in the fjord in October was estimated to be about 0.151 tonne, which is about $30 \%$ of the June estimate (Table 2). Converted to carbon (see above) this amounts to 7.6 tonnes which is, again, of the same order as the mesozooplankton biomass (amounts to 10.3 tonne C).

The total October amount of mesozooplankton was $60 \%$ of the June estimate (Table 3 ). In the upper $50 \mathrm{~m}$, however, the estimate was only $10 \%$ of the June estimate, and $90 \%$ of the biomass was located below $50 \mathrm{~m}$ in October. The numerically dominant mesozooplankton in the upper $50 \mathrm{~m}$ were Oithona spp., Pseudocalanus spp. and Acartia longiremis, while Calanus finmarchicus, Oithona spp. and Microcalanus pygmaeus dominated the layer below. The difference between the 2 layers was also reflected in the mean biomass of individuals: $3 \mu \mathrm{g}$ AFDW ind. ${ }^{-1}$ in the upper layer, and $33 \mu \mathrm{g}$ ind. ${ }^{-1}$ in the deeper layer.

The 'minimum' biomass estimate (see 'Methods') of macrozooplankton obtained with the IKMT was about half the mesozooplankton biomass estimate (Table 3). At night (Fig. 4) most tows gave estimates between 1 and $2.5 \mathrm{mg} \mathrm{AFDW} \mathrm{m}^{-3}$. During the day (Fig. 4) almost no macrozooplankton was collected in the upper $50 \mathrm{~m}$ layer (at both Stn B and S1), and the samples consisted largely of gelatinous zooplankton.

The dominant macrozooplankton species in the deeper part of the fjord were pelagic shrimps (Sergestes arcticus and Pasiphaea multidentata), euphausids (mainly Meganyctiphanes norvegica), and chaetognaths (Eukrohnia hamata and Sagitta elegans). The mesopelagic fishes Benthosema glaciale and Maurolicus muelleri were also prominent in the IKMT samples (not included in the present biomass estimates). Measured as displacement volume the fishes

Table 2. Estimates of nutrients, chl a and phaeopigment content (given as tonne) of Masfjorden during the 2 cruises. $95 \%$ confidence intervals are given. $n$ : number of samples underlying the estimates

\begin{tabular}{|c|c|c|c|c|c|}
\hline & \multirow{2}{*}{$\begin{array}{c}\text { Depth } \\
\text { strata }(\mathrm{m})\end{array}$} & \multicolumn{2}{|c|}{ June } & \multicolumn{2}{|c|}{ October } \\
\hline & & $n$ & tonne & $n$ & tonne \\
\hline $\mathrm{N}$ (as & $0-20$ & 10 & $3.3 \pm 5.5$ & 18 & $31.5 \pm 1.5$ \\
\hline nitrate) & $0-494$ & 17 & $818.2 \pm 105.8$ & 39 & $886.8 \pm 51.8$ \\
\hline $\mathrm{P}$ (as & $0-20$ & 10 & $8.0 \pm 2.7$ & 18 & $6.7 \pm 1.5$ \\
\hline phosphate) & $0-494$ & 17 & $221.0 \pm 57.3$ & 39 & $168.9 \pm 20.1$ \\
\hline Si (as & $0-20$ & 10 & $24.8 \pm 23.4$ & 18 & $49.7 \pm 15.5$ \\
\hline silicate) & $0-494$ & 17 & $1247.8 \pm 172.9$ & 38 & $1099.2 \pm 110.0$ \\
\hline $\mathrm{Chl} \mathrm{a}$ & $0-50$ & 23 & $0.497 \pm 0.208$ & 32 & $0.152 \pm 0.041$ \\
\hline Phaeopigments & $0-50$ & 23 & $0.302 \pm 0.151$ & 32 & $0.151 \pm 0.019$ \\
\hline
\end{tabular}


Table 3. Tonnes of mesozooplankton and macrozooplankton biomass in Masfjorden during the 2 cruises. $95 \%$ confidence intervals are indicated. $\mathrm{n}$ : number of samples underlying the extimates. Macrozooplankton estimates are based on night samples

\begin{tabular}{|c|c|c|c|c|c|c|}
\hline \multirow[t]{2}{*}{$\begin{array}{l}\text { Depth } \\
\text { strata }(\mathrm{m})\end{array}$} & \multicolumn{4}{|c|}{ Mesozooplankton } & \multicolumn{2}{|c|}{$\begin{array}{c}\text { Macrozooplankton } \\
\text { October }\end{array}$} \\
\hline & $n$ & tonne AFDW & $n$ & tonne AFDW & $n$ & tonne AFDW \\
\hline $0-50$ & 7 & $16.9 \pm 2.0$ & 14 & $1.6 \pm 0.3$ & 6 & $1.9 \pm 1.1$ \\
\hline $50-494$ & 5 & $15.9 \pm 3.9$ & 11 & $19.1 \pm 4.9$ & 4 & $6.3 \pm 3.7$ \\
\hline $0-494$ & 12 & $32.8 \pm 11.0$ & 25 & $20.6 \pm 11.0$ & 10 & $8.1 \pm 2.4$ \\
\hline
\end{tabular}

accounted for $37 \%$ of the total volume of the night samples obtained at Stn B.

\section{Advection of nutrients and biomass}

Daily exchange rates of water were about $2.6 \%$ and $1.0 \%$ of the total fjord volume in June and October respectively (Table 4). In June the out-transport of nutrients was similar to that of water, ranging from 2.2 to $2.6 \% \mathrm{~d}^{-1}$, but lower in October, ranging from 0.1 to $0.3 \% \mathrm{~d}^{-1}$. The biological compartments - chl a, phaeopigments and mesozooplankton - were relatively more influenced by advection with in-transport rates of $6.4,12.6$ and $13.6 \% \mathrm{~d}^{-1}$ in June, and out-transport values of $3.1,4.1$ and $0.6 \% \mathrm{~d}^{-1}$ in October (Table 4).

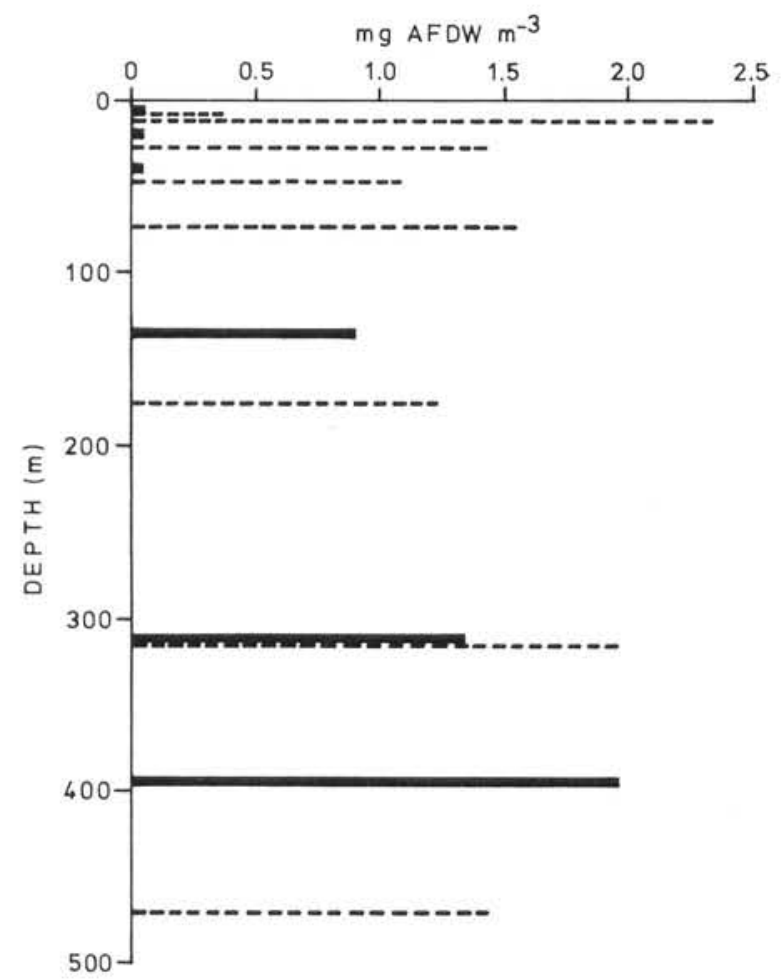

Fig. 4. Vertical distribution of macrozooplankton biomass at the deepest station (Stn B) during day (solid line) and night (broken line) during the October cruise
In June the highest mesozooplankton concentrations at the sill were associated, both day and night, with the inflowing water between 2 and $30 \mathrm{~m}$ depth, while the highest concentrations were found in the outflowing layer between 0 and $10 \mathrm{~m}$ depth in October (Fig. 2). Mesozooplankton exchange rates were much higher in June than in October (in-transport of 4.47 compared to out-transport of 0.13 tonne AFDW d ${ }^{-1}$; Table 5). This was due to the lower and deeper biomass (Table 3), and to the weaker residual currents observed in October (Fig. 2).

The influence of advection on the macrozooplankton biomass in October is estimated to be similar to that for the mesozooplankton (Table 4). It should be noted, however, that the sill IKMT-samples were clearly dominated by Meganyctiphanes norvegica both in number and biomass, indicating that this species was the main advected component in the macrozooplankton/micronekton group.

Mesopelagic fishes accounted for $18 \%$ of the displacement volume in samples obtained above $75 \mathrm{~m}$ at Stn B. At the sill station (Stn S2) this group accounted for $3 \%$, and only small individuals of Maurolicus muelleri were present. No Benthosema glaciale was obtained at this station. At Stn B, however, the biomass of $B$. glaciale was 8 times higher than the biomass of $M$. muelleri.

\section{DISCUSSION}

\section{Exchange processes}

In western Norway the tide may be the most important exchange factor in fjords with a shallow sill. But as the sill becomes deeper the role of other exchange processes increases. Masfjorden is connected with the coastal water through Fensfjorden (Fig. 1). Hydrographical observations from the period 1976 to 1980 (unpubl.) have shown that changes in the coastal current rapidly propagate into Fensfjorden and Masfjorden. Upwelling of deep water along the Norwegian coast develops 2 to $5 \mathrm{~d}$ after the onset of northerly winds. The change in the pressure field generated by the upwelling seems to flush out the upper layer on the 
Table 4. Daily exchange rates (expressed as \% of content inside the fjord) of different materials at the sill. Transport into the fjord is given in the column designated 'In', while outward transport is designated 'Out'. A negative 'Net' transport value indicates that net transport is directed out of the fjord

\begin{tabular}{|c|c|c|c|c|c|c|c|}
\hline & \multirow{2}{*}{$\begin{array}{c}\text { Depth } \\
\text { strata (m) }\end{array}$} & \multicolumn{3}{|c|}{ June } & \multicolumn{3}{|c|}{ October } \\
\hline & & In & Out & Net & In & Out & Net \\
\hline Water & $\begin{array}{l}0-20 \\
0-50 \\
0-494\end{array}$ & $\begin{array}{r}20.5 \\
10.4 \\
2.6\end{array}$ & $\begin{array}{l}0.9 \\
7.0 \\
2.6\end{array}$ & $\begin{array}{r}19.6 \\
3.4 \\
<0.1\end{array}$ & $\begin{array}{l}3.6 \\
2.9 \\
0.7\end{array}$ & $\begin{array}{l}4.5 \\
3.9 \\
1.0\end{array}$ & $\begin{array}{r}1.2 \\
-1.0 \\
-0.3\end{array}$ \\
\hline $\mathrm{N}$ (as nitrate) & $\begin{array}{l}0-20 \\
0-494\end{array}$ & $\begin{array}{l}0.0 \\
0.4\end{array}$ & $\begin{array}{l}0.0 \\
2.6\end{array}$ & $\begin{array}{r}0.0 \\
-2.2\end{array}$ & $\begin{array}{l}3.4 \\
0.2\end{array}$ & $\begin{array}{l}2.4 \\
0.3\end{array}$ & $\begin{array}{r}1.0 \\
-0.1\end{array}$ \\
\hline P (as phosphate) & $\begin{array}{l}0-20 \\
0-494\end{array}$ & $\begin{array}{r}15.5 \\
1.0\end{array}$ & $\begin{array}{l}1.1 \\
2.2\end{array}$ & $\begin{array}{r}14.4 \\
-1.2\end{array}$ & $\begin{array}{l}3.7 \\
0.1\end{array}$ & $\begin{array}{l}2.4 \\
0.1\end{array}$ & $\begin{array}{r}1.3 \\
<0.1\end{array}$ \\
\hline $\mathrm{Si}$ (as silicate) & $\begin{array}{l}0-20 \\
0-494\end{array}$ & $\begin{array}{r}4.0 \\
<0.1\end{array}$ & $\begin{array}{l}0.5 \\
2.4\end{array}$ & $\begin{array}{r}3.5 \\
-2.4\end{array}$ & $\begin{array}{l}2.4 \\
0.1\end{array}$ & $\begin{array}{l}2.9 \\
0.1\end{array}$ & $\begin{array}{r}0.5 \\
<0.1\end{array}$ \\
\hline $\mathrm{Chl} \mathrm{a}$ & $0-50$ & 6.4 & 4.6 & 1.2 & 1.4 & 3.1 & -1.7 \\
\hline Phaeopigment & $0-50$ & 12.6 & 3.6 & 9.0 & 2.6 & 4.1 & -1.5 \\
\hline Mesozooplankton & $\begin{array}{l}0-50 \\
0-494\end{array}$ & $\begin{array}{l}26.2 \\
13.6\end{array}$ & $\begin{array}{l}3.5 \\
2.8\end{array}$ & $\begin{array}{l}22.7 \\
10.8\end{array}$ & $\begin{array}{l}4.3 \\
0.3\end{array}$ & $\begin{array}{l}8.2 \\
0.6\end{array}$ & $\begin{array}{l}-3.9 \\
-0.3\end{array}$ \\
\hline Macrozooplankton & $0-494$ & & & & 0.3 & 0.6 & -0.3 \\
\hline
\end{tabular}

same time scale (Sætre et al. 1988). The processes resulting in downwelling near the coast outside Fensfjorden are more complicated. In addition to southerly winds, sudden outflows of water from the Skagerrak (southeast of Norway) may result in downwelling (Aure $\&$ Sætre 1981). The effect of such outflows may last for 10 to $20 \mathrm{~d}$. Between periods of marked coastal up- and downwelling, local processes (wind, tide and land runoff) become more important for the current regime of the fjord.

Coastal downwelling leads to in-transport of coastal water in the upper part of the intermediate layer of western Norwegian fjords, and an out-transport in the lower part. Our June situation, with inflowing water above 25 to $30 \mathrm{~m}$ depth, was most probably associated with coastal downwelling. This is supported by the wind data given in Fig. 5. After a period with northerly winds in early May, southerly winds became more prominent during late May and June.

In late October no marked transport in the intermediate layer was observed. Coastal water was present above 50 to $60 \mathrm{~m}$ depth, and the situation may be characterized as a calm period after in-transport of coastal water in the upper layer. The dominating south-

Table 5. Daily transport rates at the sill. Water is expressed as $10^{6} \mathrm{~m}^{3} \mathrm{~d}^{-1}$, other parameters as tonne $\mathrm{d}^{-1}$

\begin{tabular}{|c|c|c|c|c|c|c|c|}
\hline & $\begin{array}{c}\text { Depth } \\
\text { strata (m) }\end{array}$ & In & $\begin{array}{c}\text { June } \\
\text { Out }\end{array}$ & Net & In & $\begin{array}{c}\text { October } \\
\text { Out }\end{array}$ & Net \\
\hline Water & $\begin{array}{l}0-20 \\
0-50 \\
0-75\end{array}$ & $\begin{array}{l}112 \\
133 \\
142\end{array}$ & $\begin{array}{r}5 \\
90 \\
138\end{array}$ & $\begin{array}{r}107 \\
43 \\
-4\end{array}$ & $\begin{array}{l}20 \\
38 \\
38\end{array}$ & $\begin{array}{l}13 \\
50 \\
51\end{array}$ & $\begin{array}{r}7 \\
-12 \\
-13\end{array}$ \\
\hline $\mathrm{N}$ (as nitrate) & $\begin{array}{l}0-20 \\
0-75\end{array}$ & $\begin{array}{l}0.0 \\
2.94\end{array}$ & $\begin{array}{c}0.0 \\
20.87\end{array}$ & $\begin{array}{c}0.0 \\
-18.07\end{array}$ & $\begin{array}{l}1.06 \\
2.10\end{array}$ & $\begin{array}{l}0.77 \\
2.66\end{array}$ & $\begin{array}{r}0.29 \\
-0.56\end{array}$ \\
\hline P (as phosphate) & $\begin{array}{l}0-20 \\
0-75\end{array}$ & $\begin{array}{l}1.24 \\
2.32\end{array}$ & $\begin{array}{l}0.08 \\
4.98\end{array}$ & $\begin{array}{r}1.16 \\
-2.66\end{array}$ & $\begin{array}{l}0.25 \\
0.48\end{array}$ & $\begin{array}{l}0.16 \\
0.87\end{array}$ & $\begin{array}{r}0.09 \\
-0.39\end{array}$ \\
\hline Si (as silicate) & $\begin{array}{l}0-20 \\
0-75\end{array}$ & $\begin{array}{l}1.00 \\
5.46\end{array}$ & $\begin{array}{r}0.12 \\
30.89\end{array}$ & $\begin{array}{r}0.88 \\
-25.43\end{array}$ & $\begin{array}{l}1.17 \\
2.21\end{array}$ & $\begin{array}{l}1.46 \\
3.63\end{array}$ & $\begin{array}{l}-0.29 \\
-1.42\end{array}$ \\
\hline Chl a & $0-50$ & 0.03 & 0.02 & 0.01 & 0.002 & 0.005 & -0.003 \\
\hline Phaeopigment & $0-50$ & 0.04 & 0.01 & 0.03 & 0.004 & 0.006 & -0.002 \\
\hline Mesozooplankton & $\begin{array}{l}0-50 \\
0-75\end{array}$ & $\begin{array}{l}4.43 \\
4.47\end{array}$ & $\begin{array}{l}0.59 \\
0.91\end{array}$ & $\begin{array}{l}3.84 \\
3.56\end{array}$ & $\begin{array}{l}0.07 \\
0.07\end{array}$ & $\begin{array}{l}0.13 \\
0.13\end{array}$ & $\begin{array}{l}-0.06 \\
-0.06\end{array}$ \\
\hline Macrozooplankton & $0-75$ & & & & 0.03 & 0.05 & -0.02 \\
\hline
\end{tabular}




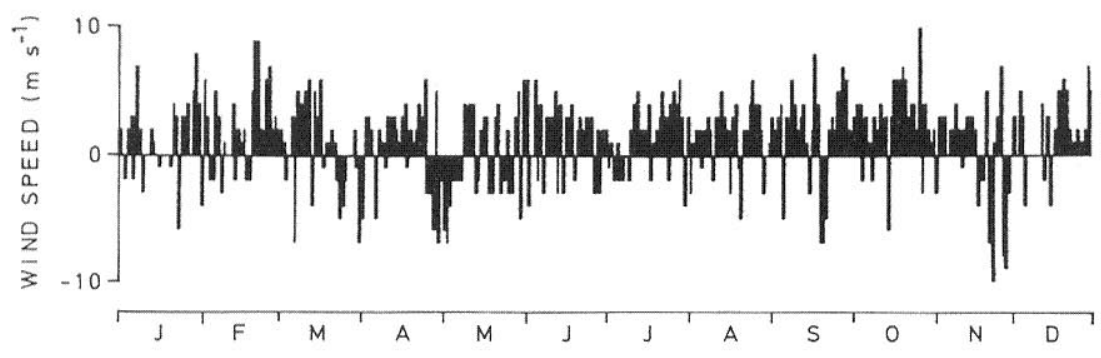

Fig. 5. Daily wind observations in Bergen during 1985. Positive $y$-values indicate southerly winds, negative values indicate northerly winds

erly winds during late September and October (Fig. 5) are probably responsible for the presence of the thick layer of coastal water.

According to the above presentation, a high frequency of alterations between southerly and northerly winds leads to an increased influence of advection. As demonstrated in Fig. 5 this frequency may be quite high. During 1985 the persistence of northerly wind events was on average lower than the persistence of southerly winds. With a too low persistence of northerly winds the role of advection may diminish. Both the frequency and the time scales of northerly wind events vary from one year to another, and these characteristics are probably the main forcing for the annual renewal of the intermediate layer of fjords located on the west coast of Norway. We suggest that a strong wind forcing may propagate effectively, through advection of the intermediate layer, into the biological compartments of the fjord. This will be discussed later, but first we will pay some attention to the deep water of the fjord.

The deep water of Masfjorden (below the sill depth) is generally not influenced by extensive transport processes. One total exchange was observed during the period 1976 to 1980 (unpubl.). The minimum oxygen concentration of the deep water was $3.7 \mathrm{mll}^{-1}$ in this period.

\section{Macrozooplankton and mesopelagic fishes in the deep water}

The deep water represents a potential refuge for pelagic organisms local to the fjord, and offers a homogeneous environment with respect to temperature and salinity (Fig. 3). This seems to be utilized by the pelagic shrimps Pasiphea multidentata, Sergestes arctica and the mesopelagic fishes Benthosema glaciale and Maurolicus muelleri. Although these species perform diel vertical migrations into the advective intermediate layer of the fjord, it is likely that they are able to sustain their horizontal distribution within the fjord (Kaartvedt et al. 1988). Excluding small numbers of Maurolicus muelleri, none of these species were present in either day or night samples collected at the sill. In contrast to the above species, the euphausid Meganyctiphanes norvegica seems to be heavily influenced by advection at night.

\section{Nutrients, chlorophyll and mesozooplankton}

If the different nutrients and organic materials had been distributed homogeneously in the fjord (and assuming passive advection) the influence on them of advection would have been the same as for water, i.e. an exchange rate of $2.6 \% \mathrm{~d}^{-1}$ in June and 0.7 to $1.0 \%$ $\mathrm{d}^{-1}$ in October (Table 4). The actual exchange rates (using the highest of the 2 values 'In' and 'Out' in Table 5) for nutrients are equal to or lower than these figures on both sampling occasions. This is to be expected since the highest nutrient concentrations of the fjord are located below the advective layer. The daily freshwater run-off amounts to only $0.1 \%$ of the fjord volume. It has a significant influence, however, on the upper $2 \mathrm{~m}$. Our June measurements (not tabulated) indicate that the freshwater run-off represents a direct input to the photic zone of about 0.4 tonne $\mathrm{Nd}^{-1}$.

Contrary to the nutrients, chl a and phaeopigments were confined to the advective layer of the fjord. During both cruises the exchange rates were 3.1 to 4.8 times higher than for water, ranging from 3.1 to $12.6 \%$ $\mathrm{d}^{-1}$ (using the highest of 'In' and 'Out' in Table 4). Such enhanced exchange was even more pronounced for the June mesozooplankton with an in-transport of $13.6 \%$ $\mathrm{d}^{-1}$, which is 5.2 times the exchange rate of water. This means that $20 \%$ of the mesozooplankton exchange was due to water advection alone, while $80 \%$ was due to the combined effect of the current profile and the vertical distribution of the mesozooplankton.

To what extent the planktonic part of a fjord system is controlled by internal biological processes rather than advective processes depends on the physical scale of the fjord versus the time scale of these processes. As a general simplification we may write:

$$
\begin{gathered}
\delta B / \delta t=r B+0.5 v R\left(B_{\mathrm{B}}-B\right) \\
R=A / V
\end{gathered}
$$

where $B=$ biomass concentration within the system 
$\left(\mathrm{mg} \mathrm{m}^{-3}\right) ; t=$ time $(\mathrm{s}) ; r=$ local instantaneous growth rate of $B\left(\mathrm{~s}^{-1}\right) ; v=$ mean absolute current above the sill $\left(\mathrm{ms}^{-1}\right) ; \quad B_{\mathrm{B}}=$ biomass concentration in incoming current $\left(\mathrm{mg} \mathrm{m}^{-3}\right) ; A=$ cross-sectional area above the sill $\left(\mathrm{m}^{2}\right) ; V=$ fjord volume $\left(\mathrm{m}^{3}\right)$.

As $B$ approaches $B_{\mathrm{B}}$ the net advective effect becomes zero. This does not mean, however, that the advective effect has ceased, since the biomass renewal within the system still may be dominated by advection rather than local growth. The growth rate $(r)$ and the advective rate $(\beta=0.5 v R)$ have the same dimension $\left(\mathrm{s}^{-1}\right)$, and the ratio $r / \beta$ decides which of the 2 processes dominates the biomass formation within the system. If $r / \beta>1$, growth is the dominating process while $r / \beta<1$ indicates advective dominance. The importance of advection relative to the growth of phytoplankton and zooplankton is indicated in Fig. 6. The much lower growth rate of zooplankton compared with phytoplankton implies that transport influences primarily the zooplankton biomass (Fig. 6). Phytoplankton is, however, constrained to the upper, photic zone where transport processes are most prominent. Zooplankton may utilize the entire water column and the advective influence may thereby diminish. A quantitative effect of this is demonstrated in Fig. 6. We see that the zooplankton confined to the advective layer (dotted line) is 3 times more influenced by advection than zooplankton distributed in the entire fjord volume (solid line). Similarly, vertical migrations (diel and seasonal) may also reduce the influence of advection for populations depending on the food availability in the advective layer. This is demonstrated by the October

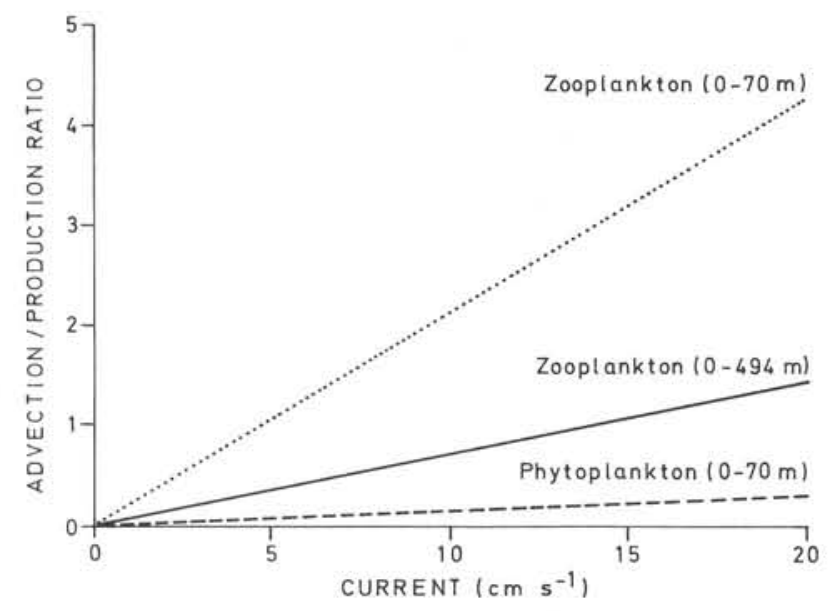

Fig. 6. Scale analysis on the role of advection relative to production. $Y$-values above 1 indicate that advection dominates over production in the formation of plankton biomass in the fjord. The $\mathrm{x}$-axis represents the mean absolute current above the sill. Plankton is assumed to be distributed homogeneously throughout the depth interval indicated. Growth rate of zooplankton was assumed to be $5 \% \mathrm{~d}^{-1}$; doubling time of phytoplankton was assumed to be $1 \mathrm{~d}$ results where $90 \%$ of the mesozooplankton (Table 3 ) was distributed below $50 \mathrm{~m}$. This distribution resulted in an exchange value $\left(0.6 \% \mathrm{~d}^{-1}\right)$ that was lower than the water exchange value $\left(0.7\right.$ to $\left.1.0 \% \mathrm{~d}^{-1}\right)$. A deep localization of the mesozooplankton during late autumn and winter is the normal situation in Norwegian fjords.

From Eqs. (1) and (2) we see that the value of $R$ (ratio between the cross-sectional area above the sill and the fjord volume) gives the order of magnitude of the advective influence in a particular system. This ratio varies considerably from one fjord to another (see 'Introduction'), and it may serve as an index indicating the potential advective influence on a system. As shown above, the product of $R$ and the typical current velocity $(v)$ across the boundary surface $(A)$ is a quantity with a dimension $\left(\mathrm{s}^{-1}\right)$ equal to the dimension of biological processes rates. A direct comparison of these rates may therefore be performed.

The highest exchange rate of chl a was $6.4 \% \mathrm{~d}^{-1}$. In June, a phytoplankton doubling time of $1 \mathrm{~d}$ is not unrealistically high. This corresponds to a $100 \%$ increase each day, and local growth was probably the dominating process of the phytoplankton biomass renewal in the fjord.

The primary production seems to be strongly limited by the availability of nitrate in June, which is probably the normal situation during summer. Assuming a $\mathrm{N}$ : chl ratio of 8 and an average phytoplankton doubling time of $1 \mathrm{~d}$, the estimated phytoplankton stock of 0.497 tonne chl a within the fjord (Table 2) may utilize about 4 tonne nitrate $\mathrm{d}^{-1}$. The 0.4 tonne nitrate supplied by the freshwater run-off accounts for only $10 \%$ of this potential nutrient uptake. Factors influencing the transport of new nutrients into the photic zone from below are therefore of major importance for the new production within the fjord.

While no advection of nitrate was measured in the upper $20 \mathrm{~m}$ in June (Table 5), an amount of 18 tonne nitrate $d^{-1}$ was exported below this depth (Table 5). Although most of this nitrate was exported below the photic zone, such losses may affect the future vertical transport of nitrate from non-photic to photic zone. Hence, advective nutrient loss in the layer close to the photic zone may lead to reduced new production within the fjord. The loss of 18 tonne nitrate $\mathrm{d}^{-1}$ exceeds the assumed daily growth by a factor of 4 , and advective nutrient exchange (even below the euphotic zone) may therefore be of greater importance to the primary production than the exchange of the phytoplankton itself.

The above nutrient loss may be turned into nutrient supply in the case of northerly winds. In this situation the lower part of the intermediate layer may be enriched by nutrients, and thereby give rise to an increased new production. 


\section{Earlier observations at the head of Masfjorden}

Daily measurements of the zooplankton biomass in the intake water of the aquaculture station in Matre (Fig. 7) were made in the years 1976 to 1978 (Anon. 1980). The seawater intake of the station is located at $10 \mathrm{~m}$ depth at the head of the fjord (inwards of Stn D; Fig. 1), and the zooplankton measurements were obtained by filtering $(500 \mu \mathrm{m})$ the intake water. The samples were dominated by Calanus finmarchicus. A physical/biological aggregation mechanism rather than local production is probably the explanation for the very high biomass observations (Fig. 7). The biomass build up corresponds to an average increase as high as 10 to $20 \% \mathrm{~d}^{-1}$. Such an increase may be explained by advective rates similar to those observed in June. At this time, the net in-transport of mesozooplankton at the sill was estimated to be $22.7 \% \mathrm{~d}^{-1}$ in the upper $50 \mathrm{~m}$ (Table 4). The marked decrease in biomass in May and June (Fig. 7) may be due to advection, mortality or migration. As a result of downward migration, Calanus finmarchicus is known to disappear from the upper water column in Norwegian fjords during late spring (Aksnes \& Magnesen 1983).

\section{Mesozooplankton advection and higher trophic levels}

Mesozooplankton is the main diet of cod fry less than $5 \mathrm{~cm}$, while the cod between 5 and $20 \mathrm{~cm}$ feed predominantly on Gobiusculus flavescens in Masfjorden (Salvanes 1986). Investigations on this species are currently undertaken and the diet is reported to be mesozooplankton (Fosså pers. comm.). In fjords of northern Norway Maurolicus muelleri, Benthosema glaciale and Pasiphaea sp. are reported to be prey items of cod (Santos \& Falk-Petersen 1988), and these species are also possible prey items for the cod in
Masfjorden. The diet of $B$. glaciale and $M$. muelleri is mesozooplankton (Gjøsæter 1973, 1981).

Coastal cod has long been regarded 'as geographically stationary (Dahl 1906), and release experiments with artificially propagated cod (Svåsand 1985) support this. The nearshore living Gobiusculus flavescens and the mesopelagic shrimps and fishes are also believed to be part of a local fjord community, at least when compared to the mesozooplankton. We therefore think that the relation between the stationary mesozooplankton predators and the advected prey is an important feature of fjord ecology.

A simplified relationship between a stationary predator (C) in the fjord, and a zooplankton prey (B) influenced by both local growth and transport may be expressed:

$$
\begin{gathered}
\delta B / \delta t=r B(1-B / K)-a B C+\beta\left(B_{\mathrm{B}}-B\right) \\
\delta C / \delta t=a e B C-d C
\end{gathered}
$$

where $B=$ prey concentration within the system; $B_{\mathrm{B}}=$ prey concentration at the boundary; $C=$ predator concentration within the system; $r=$ instantaneous growth rate of $\mathrm{B}$ when predator is absent; $K=$ carrying capacity (equilibrium biomass attained by prey when predator and advection are absent); $a=$ predation constant; $\beta=$ instantaneous exchange rate of the system due to advection, corresponds to $0.5 v R$ in Eq. (1); $e=$ conversion efficiency; $d=$ death rate of predator $(C)$.

If the net advective rate, $b=0$ (no advection of prey), the above equations correspond to the Lotka-Volterra equations.

The equilibrium biomasses of prey $\left(B^{\prime}\right)$ and predator $\left(C^{\prime}\right)$ are:

$$
\begin{gathered}
B^{\prime}=d / a e \\
\left.C^{\prime}=1 / a\left(r\left[1-B^{\prime} / K\right]\right)+\beta\left[B_{\mathrm{B}} / B^{\prime}-1\right]\right)
\end{gathered}
$$

According to this equilibrium solution, the prey equilibrium biomass $\left(B^{\prime}\right)$ is not influenced by the exchange

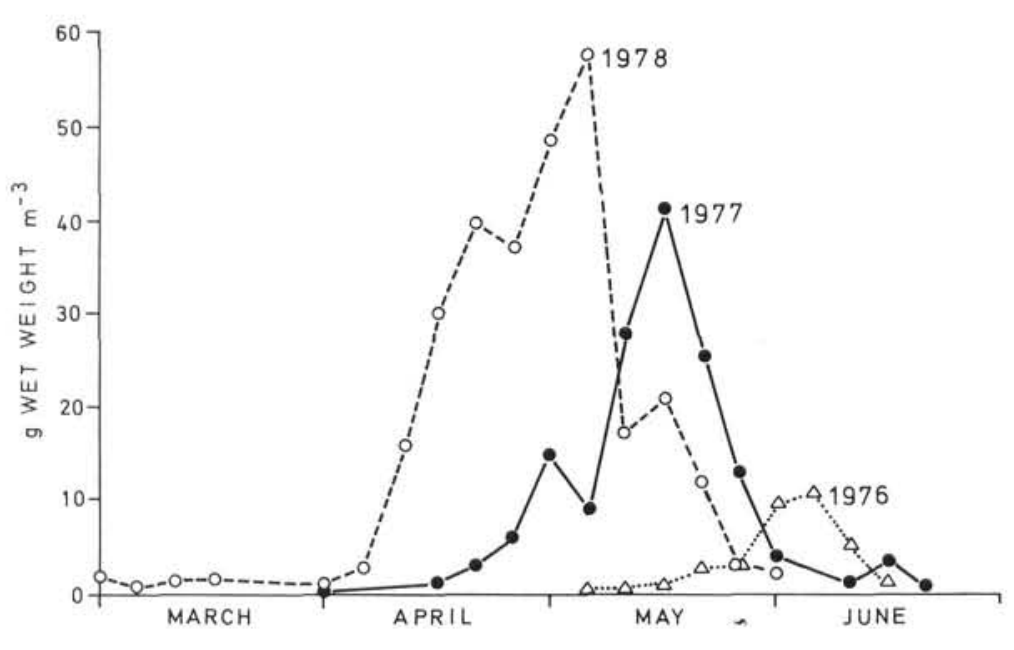

Fig. 7. Zooplankton content ( $5 \mathrm{~d}$ running mean) of the intake water of the Matre aquaculture station located at the head of the fjord (inwards of Stn D) (redrawn from Anon. 1980) 
rate $(\beta)$ or the boundary biomass $\left(B_{\mathrm{B}}\right)$. The predator biomass $\left(C^{\prime}\right)$, however, responds linearly to a change in both the exchange rate and the boundary biomass.

We may rewrite Eq. (6):

$$
C^{\prime}=1 / a\left(r\left[1-B^{\prime} / K\right]+b\right),
$$

where $b$ may be termed the net advective rate of the prey, which corresponds to the net exchange rate in Table 4 (expressed as a finite percentage in the Table). We see that a change in the growth rate $(r)$ of the prey also affects the predator equilibrium biomass $\left(C^{\prime}\right)$ linearly, but the effect is suppressed by the factor $1-B^{\prime} / K$. This means that the predator biomass is more sensitive (depending on how close the prey biomass is to its carrying capacity) to a change in the net advective rate $(b)$ than to a change in the growth rate of the prey $(r)$. This, of course, relies on the assumption that the advective biomass is equally available to the predator as the biomass originating from local production. The estimates of $b$ for the mesozooplankton were $0.10 \mathrm{~d}^{-1}$ (corresponds to $10.8 \%$ in Table 4) in June. Assuming a growth rate for the entire population of $0.05 \mathrm{~d}^{-1}$ and that the 'equilibrium' biomass was half the carrying capacity, the 'local' contribution to the zooplankton predator would have been 0.025 while the advective contribution would have been 4 times this figure $(0.10)$. It must be noted that if the upper 0 to $50 \mathrm{~m}$ is considered separately the significance of advection is even more pronounced $\left(22.7 \% \mathrm{~d}^{-1}\right.$; Table 4$)$. The estimate of $b$ in October was considerably less and had a negative sign $(-0.003)$. At this time, however, the growth rate of the mesozooplankton was probably also suppressed.

\section{CONCLUSIONS}

The growth rate of phytoplankton (in the productive season) is probably high enough to dominate the biomass renewal in the Masfjord. This seems to be true even at times with high advection across the sill boundary. During summer, supply of nutrients from below may be the main nutrient source for new production. Advection of nutrients in the intermediate layer below the photic zone may be high enough to severely influence the future vertical transport of nutrients into the photic zone.

The wind regime along the Norwegian coast is probably the main forcing for the renewal of the intermediate layer of the Masfjord. Variability in this wind regime may create variability in the new production of the fjord. This variability may further propagate into a variability in the carrying capacity for the higher trophic levels.

The advection of mesozooplankton results in a more direct influence on the carrying capacity of higher levels. It is shown that a stationary predator relying on the availability of mesozooplankton in Masfjorden may be strongly influenced by mesozooplankton advection. Young cod belong to this group of predators. Both the actual level of biomass and the stability of the fjord populations may depend on the strength and variability of the transport processes. In an advective system the resident mesozooplankton predators are not a part of a usual predator prey relationship as described by the classical Lotka-Volterra equations. In the advective system the predator cannot exterminate their prey and in that sense the system may be stabilized. On the other hand, variability in the advection itself may propagate into the system. Furthermore, most predators have pelagic larvae that are transported via currents, and recruitment may therefore be influenced positively or negatively by advection. Future research concentrating on the impact of advection on an annual basis (the time scale of the predators' life cycle) is necessary in order to obtain a thorough understanding of the coupling between advection, stability and carrying capacities of predators in fjords.

Acknowledgements. We thank A. Aadnesen for field and laboratory assistance, and U. Lie, T. Høisæter, J. H. Fosså and J. Giske for stimulating discussions and commenting on the manuscript. We also acknowledge the meteorological data given by the Norwegian Meteorological Institute, and the financial assistance from Fiskeridirektoratets Effektiviseringsmidler and from the Newfoundland Institute for Cold Ocean Science and the Canadian-Scandinavian Foundation.

\section{LITERATURE CITED}

Aksnes, D. L. (1986). Resource allocation in the study of copepod population dynamics. Dr scient. thesis, Univ. Bergen

Aksnes, D. L., Magnesen, T. (1983). Distribution, development, and production of Calanus finmarchicus (Gunnerus) in Lindåspollene, western Norway, 1979. Sarsia 68: $195-208$

Anon. (1980). Havmiljø og Havundersøkelser i de norske fiskeriområder. Fisken og Havet 1980 (Sæernummer 1): 1-61

Anon. (1981). Manual for the international young fish surveys in the North Sea, Skagerak and Kattegat. Coun. Meet. int. Coun. Explor. Sea C.M.-ICES/H: 9, p. A.0.-B.3

Aure, J., Sæetre, R. (1981). Wind effects on the Skagerak outflow. In: Sætre, R., Mork, M. (eds.) The Norwegian coastal current. University of Bergen, p. 263-293

Cochran, W. G. (1977). Sampling techniques, 3rd edn. John Wiley \& Sons Inc., New York

Dahl, K. (1906). Undersøgelser over nytten av torskeudklækning $\mathrm{i}$ østlandske fjorde. Betenkning. Årsberetn. Norg. Fisk. 1: 3-97

Gjøsæter, J. (1973). The food of the myctophid fish Benthosema glaciale (Reinhardt), from western Norway. Sarsia 52: $53-58$

Gjøsæter, J. (1981). Life history and ecology of Maurolicus muelleri (Gonostomatidae) in Norwegian waters. FiskDir. Skr. (Ser. Havunders.) 17: 109-131 
Holm-Hansen, O., Lorenzen, C. J., Holmes, R. W., Strickland, J. D. H. (1965). Fluorometric determination of chlorophyll. J. Cons. int. Explor. Mer 30: 3-15

Kaartvedt, S., Aksnes, D. L., Aadnesen, A. (1988). Winter distribution of macroplankton and micronekton in Masfjorden, western Norway. Mar. Ecol. Prog. Ser. 45: 45-55

Lie, U., Magnesen, T., Tunberg, B., Aksnes, D. (1983). Preliminary studies on the vertical distribution of size-fractions in the zooplankton community in Lindåspollene, western Norway. Sarsia 68: 65-80

Lindahl, O., Hernroth, L. (1988). Long-scale and long-term variations in the zooplankton community of the Gullmar fjord, Sweden, in relation to advective processes. Mar. Ecol. Prog. Ser. 43: 161-171

Lindahl, O., Perissinotto, R. (1987). Short-term variations in the zooplankton community related to water exchange processes in the Gullmar fjord, Sweden. J. Plankton Res. 9: 1113-1132

Matthews, J. B. L., Heimdal, B. R. (1980). Pelagic productivity and food chains in fjord systems. In: Freeland, H. J., Farmer, D. M., Levings, C. D. (eds.) Fjord oceanography. Plenum Publ. Corp., New York, p. 377-398
Platt, T., Conover, R. J. (1971). Variability and its effect on the $24 \mathrm{~h}$ chlorophyll budget of a small basin. Mar. Biol. 10: 52-65

Salvanes, A. G. V. (1986). Preliminary report from a comparative study of the diet of four gadoid fishes in a fjord of western Norway. Coun. Meet. int. Coun. Explor. Sea C.M.ICES/G: 71: 1-18

Santos, J. Dos, Falk-Petersen, S. (1988). Feeding ecology of cod (Gadus morhua L.) in Balsfjord and Ullsfjord, North Norway, 1982-83. J. Cons. int. Explor. Mer (in press)

Sætre, R., Aure, J., Ljøen, R. (1988). Wind effects on the lateral extension of the Norwegian Coastal water. Cont. Shelf Res. 9: 239-253

Svåsand, T. (1985). Preliminary results form tagging and release of artificially reared 0-group coastal cod (Gadus morhua L.) in western Norway. Coun. Meet. int. Coun. Explor. Sea C.M.-ICES/F: 9: 1-18

Ulltang, $\varnothing$. (1984). The management of cod stocks with special reference to growth and recruitment overfishing and the question whether artificial propagation can help to solve management problems. In: Dahl, E., Danielssen, D. S., Moksness, E., Solemdal, P. (eds.) The propagation of Cod Gadus morhua L. Flødevigen rapportser. 1, p. 795-817

This article was submitted to the editor; it was accepted for printing on September 28, 1988 